\title{
SPIRORBIS CORALLINAE N.SP. AND SOME OTHER SPIRORBINAE (SERPULIDAE) COMMON ON BRITISH SHORES
}

\author{
By P. H. D. H. De Silva AND E. W. Knight-Jones \\ Department of Zoology, University College of Swansea
}

(Text-fig. I)

The Spirorbinae of Britain have not previously been studied carefully. A remarkable omission from widely used British fauna lists (Marine Biological Association, I93I ; Eales, 1939, 1952) was Spirorbis pagenstecheri Quatrefages, which is by far the most generally common dextral species on British shores. Instead S. spirillum (Linné) was the only dextral species recorded in those lists, with no note of the fact that this is typically an off-shore form. Several accounts of shore ecology which mention the latter but not the former may have involved misidentifications from this cause.

Another source of confusion was that McIntosh (1923) described under the name $S$. granulatus (Linné) a common British species which incubates its embryos in its characteristically ridged tube. In fact the first adequate description to which that name was applied was of a species with an opercular brood chamber (Caullery \& Mesnil, I897). It is therefore incorrect to apply the name to a form with tube incubation, unless one supposes that the method of incubation is variable in this species. Although Thorson (1946) was inclined to make that assumption it is unlikely to be true, for incubation in the operculum involves striking specializations of structure, function and habits. Indeed it is now virtually certain that two separate species are involved here, as Bergan (1953) concluded in his account of the Spirorbinae of Norway.

Bergan, however, regarded this ridged, tube-incubating form as a mere variety of S. borealis Daudin. We believe, with Höglund (I95I), that it should be separated under the name $S$. tridentatus Levinsen. This conclusion follows from experiments on the attachment behaviour of the larvae (de Silva, 1962a), which also showed that there is another closely related form common on British shores. This is described here under the name $S$. corallinae sp.nov. Briefly, larvae of $S$. corallinae choose to settle on the alga Corallina officinalis L., those of $S$. borealis on Fucus serratus L. and those of S. tridentatus on stones. The larvae will not settle readily on substrata characteristic of the other two species.

Besides these differences in behaviour there are other biological differences between these forms (de Silva, 1962 b) and there are also small morphological

\footnotetext{
* Now at the Colombo National Museum, Ceylon.
} 
differences which are described here and which confirm that they should be regarded as distinct species. A fourth closely related species, $S$. rupestris Gee \& Knight-Jones, 1962, has been described elsewhere but is included here in a key to the common British Spirorbinae.

The material on which this account is based was collected from near Swansea, Aberystwyth, Menai Bridge, Milford Haven, Millport, Plymouth, Port Erin and Robin Hood's Bay. The collection of British Spirorbis in the British Museum (Natural History) was also examined.

\section{DESCRIPTION OF SPECIES}

\section{Spirorbis (Laeospira) corallinae sp.nov.}

Tube sinistral, white, smooth, opaque, calcareous and circular in cross-section (Fig. II). Whorls 3 to 4 , the inner usually conspicuous. Maximum diameter across outer whorl about $2.5 \mathrm{~mm}$. Tentacles 7 or occasionally 8 , with terminal filaments from $\mathrm{I} \frac{1}{2}$ to 3 times as long as the distal pair of pinnules. Opercular plate somewhat funnelshaped with a well-developed, characteristically bifid proximal process or 'talon' (Fig. I J, K).

Thorax of three setigerous segments. Collar setae with about 9 serrations adjoining the terminal blade, gradually decreasing in size proximally (Fig. IL).

Setigerous abdomen of $16-25$ segments, the first two being female. Total body length up to $3.5 \mathrm{~mm}$.

Body colour. Tentacles generally orange, brighter towards base. Blood vessels within green, but rather obscured by pigment of the tentacles. Collar, thorax and abdomen bright orange to red. Posterior third of abdomen paler. Oesophagus Moorish blue (Wilson, 1938, 1940) or brown. Hepatic pigment umber brown.

Reproduction. About 20 embryos at a time are incubated in the tube. Ripe ova dark brown and $0.1-0.15 \mathrm{~mm}$ in maximum diameter. Larvae $0.25-0.35 \mathrm{~mm}$ long, orange tinged yellow, with two pairs of abdominal uncini adjoining the anus, an apical tuft of cilia, two pairs of eye spots (the anterior being smaller) and a mid-dorsal attachment gland.

Habitat. On Corallina officinalis and a few other algae

\section{Spirorbis (Laeospira) borealis Daudin}

Serpula spirorbis Linné, $1758,787$.

Spirorbis borealis Daudin, $1800,38$.

S. linnei Malm, 1874, 103.

Tube sinistral, white, smooth, opaque and calcareous, with its base of attachment to the substratum widened peripherally (Fig. IA). Whorls 3 to 4 , the inner usually conspicuous. Maximum diameter across outer whorl about $4 \mathrm{~mm}$. Tentacles 8 or 9 , occasionally 7 or 10, with terminal filaments only slightly longer than the distal pair of pinnules. Opercular plate almost flat, with a very short and blunt proximal process from one margin (Fig. IB).

Thorax of three setigerous segments. Collar setae with 4-6 coarse serrations, which are fairly uniform in size, adjoining the terminal blade (Fig. ID).

Setigerous abdomen of 20-30 segments, the first two or three being female. Total body length up to $6.5 \mathrm{~mm}$.

Body colour. Tentacles colourless, tinged green by the blood vessels within. Collar and thorax colourless or tinged with red. Abdomen marked segmentally with red 
pigment spots. Posterior third of abdomen colourless, tinged green by blood. Hepatic pigment blue or brown.

Reproduction. About 50 embryos at a time incubated in tube. Ripe ova dark brown and $0.1 \mathrm{I}-0.19 \mathrm{~mm}$ in maximum diameter. Larvae $0.33-0.4 \mathrm{~mm}$ long, orange coloured, with three pairs of abdominal uncini but otherwise like those of $S$. corallinae.

Habitat. On Fucus serratus and other algae.

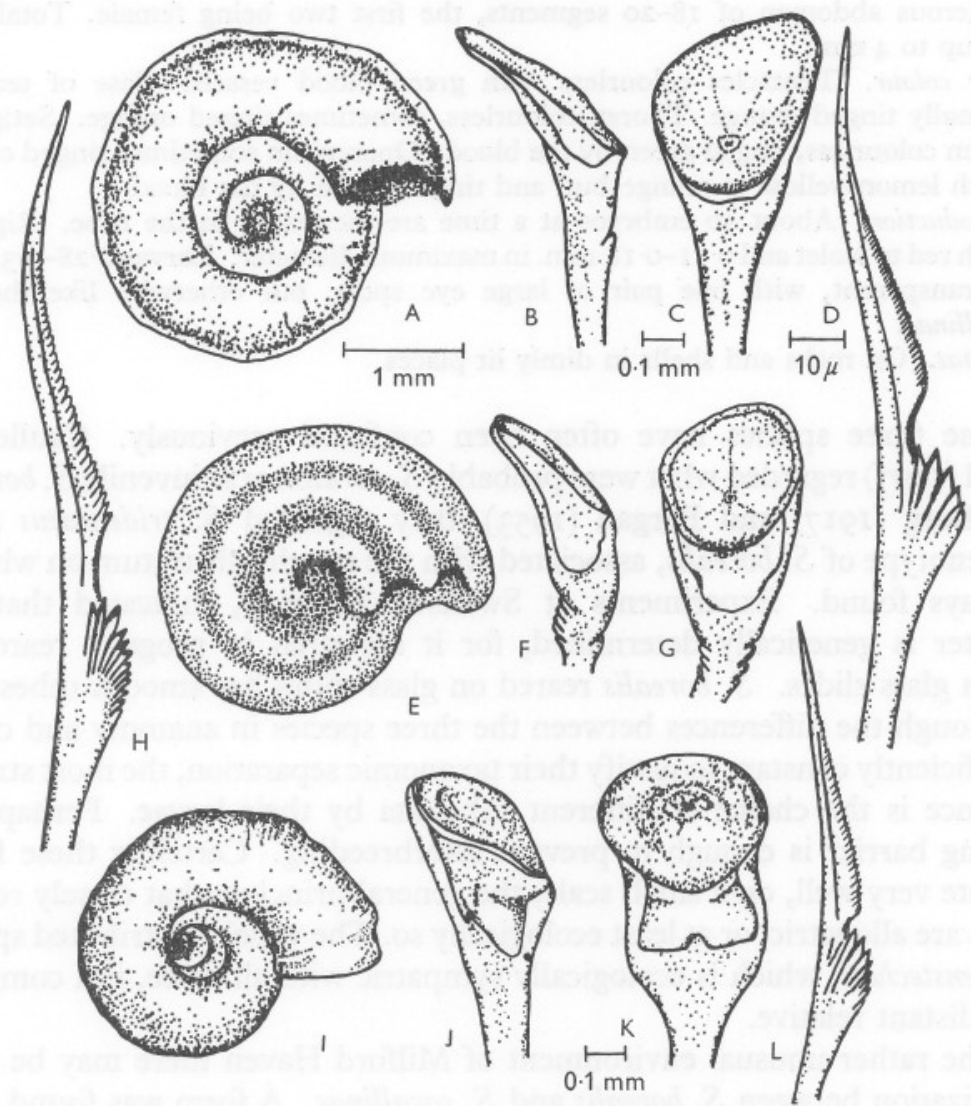

Fig. I. A-D, Tube, operculum (lateral and ventral views) and collar seta of S. borealis; E-H, the same for $S$. tridentatus; I-L, the same for $S$. corallinae.

\section{Spirorbis (Laeospira) tridentatus (Levinsen)}

$S$. granulatus var. tridentatus Levinsen, I883, $31 \mathrm{I}$.

S. borealis var. tridentatus Borg, $1917,23$.

$S$. granulatus McIntosh, I923, 400.

$S$. tridentatus Höglund, I95I, 26I.

S. borealis var. tridentatus Bergan, 1953, 33.

Tube sinistral, dull white or brown, opaque and calcareous, with three longitudinal ridges prolonged round the mouth as blunt teeth (Fig. IE). Whorls 3 to 4 , with the outer whorl widening rapidly towards the mouth and tending to hide thei nner whorls. 
Maximum diameter across outer whorl about $3.5 \mathrm{~mm}$. Tentacles 9 or 10, with terminal filaments $\mathrm{I} \frac{1}{2}$ to 3 times as long as distal pinnules. Opercular plate funnel-shaped and with a rounded proximal process or talon (Fig. IF, G).

Thorax of three setigerous segments. Collar setae with a least I2 serrations adjoining the gap which marks off the terminal blade, forming a long series of teeth which decrease in size proximally (Fig. $1 \mathrm{H}$ ).

Setigerous abdomen of $18-20$ segments, the first two being female. Total body length up to $4 \mathrm{~mm}$.

Body colour. Tentacles colourless with green blood vessels. Base of tentacles occasionally tinged orange. Thorax colourless, sometimes tinged orange. Setigerous abdomen colourless, tinged green by the blood. Operculum sometimes tinged orange. Stomach lemon-yellow to orange-buff and tinged green by the blood.

Reproduction. About 50 embryos at a time are incubated in the tube. Ripe ova purplish red to violet and $0.1 \mathrm{I}-0 . \mathrm{I} 8 \mathrm{~mm}$. in maximum diameter. Larvae $0.28-0.35 \mathrm{~mm}$. long, transparent, with one pair of large eye spots, but otherwise like those of S. corallinae.

Habitat. On rocks and shells in dimly lit places.

These three species have often been confused previously. Caullery \& Mesnil (1897) regarded what were probably $S$. corallinae as juvenile $S$. borealis. With Borg (1917) and Bergan (1953), they regarded $S$. tridentatus as an ecophenotype of $S$. borealis, associated with the rough substratum on which it is always found. Experiments at Swansea, however, indicated that this character is genetically determined, for it appeared in progeny reared on smooth glass slides. S. borealis reared on glass slides has smooth tubes.

Although the differences between the three species in anatomy and colour are sufficiently constant to justify their taxonomic separation, the most striking difference is the choice of different substrata by their larvae. Perhaps the resulting barrier is enough to prevent interbreeding. Certainly these forms illustrate very well, on a small scale, the general principle that closely related species are allopatric, or at least ecologically so. The widely distributed species $S$. pagenstecheri, which is ecologically sympatric with all three, is a comparatively distant relative.

In the rather unusual environment of Milford Haven there may be some hybridization between $S$. borealis and $S$. corallinae. A form was found there at Lawrenny, on Fucus serratus and Laminaria hyperborea, which resembled typical $S$. borealis in colour and size, but resembled $S$. corallinae in the form of the collar setae and opercular 'talon' and in having, apparently, only two pairs of uncini in the larvae. When larvae of this form were offered a choice between substrata in experimental dishes, I57 settled on F. serratus and I4 on Corallina officinalis. In further experiments involving a choice between three algae, II3 settled on F. serratus, 65 on L. hyperborea and 8 on C. officinalis. To judge from this behaviour, the form may be regarded provisionallv as a local variety of $S$. borealis. 


\section{KEY TO SOME COMMON BRITISH SPECIES OF SPIRORBIS}

The species examined by us and mostly identified from Fauvel (1927) may be distinguished as follows:

I. Dextral (mouth of tube faces anti-clockwise).

Sinistral (mouth of tube faces clockwise).

2. Incubation in operculum; tube often ridged and brown.

Incubation in tube, which is smooth and porcellanous. S. spirillum (Linné)

S. pagenstecheri Quatrefages

3. Incubation in operculum; tube with longitudinal ridges. S. granulatus (Linné) Incubation in tube.

4. Tube with longitudinal ridges.

Tube without longitudinal ridges.

6

5. Talon (proximal process of opercular plate) pointed, so that opercular plate resembles drawing pin.

$S$. malardi Caullery \& Mesnil

Talon rounded and marginal (Fig. IF).

S. tridentatus Levinsen

6. Talon scarcely distinguishable; body greenish brown; tube with base of attachment to substratum widened peripherally; coil diameter up to $4 \mathrm{~mm}$.

S. borealis Daudin

Talon well developed; body red; tube with base of attachment to substratum not widened peripherally.

7. Talon bifid, divided by a deep groove; coil diameter up to $2.5 \mathrm{~mm}$; substratum Corallina, Chondrus or Gigartina. $\quad S$. corallinae de Silva \& Knight-Jones

Talon with only a shallow terminal notch; coil diameter up to $4 \mathrm{~mm}$; substratum rocks or Lithophyllum. S. rupestris Gee \& Knight-Jones, 1962

The only other well recognized species recorded from the British Isles, so far as we are aware, are $S$. violaceus Levinsen and $S$. militaris Claparède from the Channel Islands (McIntosh, 1923) and S. pusilloides Bush and S. medius Pixell from Ireland (Southern, I9I4). The name Serpula corrugata was given by Montagu ( 1803 ) to a form occurring on rocks in Devonshire, but the description was inadequate and may well have referred to Spirorbis pagenstecheri. We cannot yet claim as British the species Fauvel (1927) called S. corrugatus (Montagu).

\section{NOTES ON DISTRIBUTION}

Our field observations have been confined to Wales and south-west England (see Gee \& Knight-Jones, I962) and to Essex, particularly near Burnham-onCrouch. Spirorbis thrives best on western coasts of Britain, where there are rock pools, algae and clear water. It is practically absent from the Essex creeks. Of the various species Spirorbis pagenstecheri seems the most tolerant of turbid estuarine conditions, but has been unable to establish itself successfully in Essex creeks, although large living populations were introduced over many successive years on oysters imported from France and relaid in the River 
Roach near Paglesham and on other oyster beds. On the west coast of Britain the number of species and abundance of littoral Spirorbis decrease in shallower and more turbid estuaries and bays. At Barmouth, for instance, only $S$. pagenstecheri could be found.

The species which is next in tolerating turbid conditions appears to be $S$. tridentatus, which was seen on the shore at Sully Island, near Cardiff, and the Little Orme, near Llandudno, where the species associated with algae seemed to be absent. The least tolerant of such conditions is $S$. rupestris. But in very sheltered places such as Milford Haven, this and other species can live in turbid water. It seems to be the combination of turbidity with wave action, to produce scouring, which is fatal to those littoral species which live on algae. Many S. pagenstecheri and S. tridentatus are protected from scouring by living under stones and in deep crevices. The thick tube of $S$. tridentatus, strengthened by ridges, is an additional protection.

Whilst searching shores we failed to find $S$. granulatus, $S$. malardi or S. spirillum, but the latter is abundant and widespread below tidemarks. The following notes apply to most rocky western shores, including Plymouth Hoe and Dale Fort. Some details of the littoral zonation of certain species at Dale are given by Moyse \& Nelson-Smith (1962).

\section{Spirorbis borealis}

Mostly on Fucus serratus, but may also occur on F. vesiculosus, Laminaria saccharina, Ulva lactuca and some other algae, but not on Corallina or Lithophyllum. Occasionally on stones or shells. Generally below low water neap tides, but higher in pools. Locally abundant, particularly in sheltered places and pools. Scarce or absent on many wave-exposed shores in Cardigan Bay and the Bristol Channel.

\section{Spirorbis corallinae}

Almost exclusively on Corallina officinalis; sparsely on Chondrus crispus and Gigartina stellata. In pools on lower half of shore and also below tide marks, where it grows to particularly large size. Generally more abundant than $S$. borealis, but scarce or absent on certain shores where Corallina is quite abundant, e.g. Llanddwyn, Newquay, Nash Point and Lyme Regis. These places adjoin wide sandy areas where sublittoral Corallina must be scarce, which suggests that occasional recolonization of rock pools from deeper water may be important in maintaining littoral populations. Where it is scarce, $S$. corallinae is absent from the great majority of rock pools but abundant in some, which indicates that the pelagic life is short.

\section{Spirorbis granulatus}

Not found by us but recorded from shells dredged at Plymouth by Höglund (Marine Biological Association, 1957).

\section{Spirorbis malardi}

A few found by Mr M. P. Harris on shells embedded in Laminaria holdfasts below tide marks in North Haven, Skomer; also in a similar habitat opposite the Plymouth Laboratory. 


\section{Spirorbis pagenstecheri}

On rocks, stones, shells, Laminaria saccharina in sheltered inlets, basal parts of Ascophyllum nodosum and occasionally on Fucus serratus, F. vesiculosus, Chondrus crispus, Polyides rotundus, Ceramium rubrum, Ulva lactuca, Enteromorpha intestinalis and Cladophora sericea. Very abundantly on Corallina officinalis in rock pools in the upper half of the shore. From below tide marks to near high water of neap tides in deep, shaded crevices and even higher in rock pools. The most widespread and generally abundant species observed.

\section{Spirorbis rupestris}

On stones and rocks, generally in concavities and crevices which are well illuminated but protected from abrasion. Usually associated with the encrusting coralline alga Lithophyllum, in which the tubes are often deeply embedded. Extending throughout lower half of shore, both in and out of pools. The highest groups occur in shaded crannies or under Ascophyllum. Generally abundant round Devon and Cornwall and to the west and north of Pembrokeshire, Carnarvonshire and Anglesey.

\section{Spirorbis spirillum}

Often found on the ventral side of lobsters, inside shells inhabited by large Eupagurus bernhardus and on the hydroids Hydrallmania falcata and particularly Abietinaria abietina. Common and occasionally abundant below tide marks.

\section{Spirorbis tridentatus}

On rocks, stones and shells in shaded gullies, crevices, deep pools and caves. Not found on algae, except occasionally on the basal parts of Corallina officinalis. From below tide marks to about half tide. Generally abundant.

We are grateful, for facilities during part of this work, to the Director of the Plymouth Laboratory and the Warden of the Dale Fort Field Centre, and for collections of material, to Dr T. B. Bagenal of Millport, Dr N. S. Jones of Port Erin, Dr F. Segrove of Sheffield and the late Professor T. A. Stephenson, F.R.S., of Aberystwyth. We must also thank Miss Angela Edwards, of the British Museum (Natural History), for help in examining the Museum's collection of Spirorbinae, and Mr J. M. Gee for most of the drawings in Fig. I.

\section{SUMMARY}

Spirorbis corallinae sp.nov. is very similar to $S$. borealis but can be distinguished by its orange colour, small size, bifid opercular talon and particularly by the fact that the larvae choose to settle on Corallina officinalis rather than on Fucus serratus.

Other species dealt with, in a key to identification and notes on distribution, are S. granulatus, S. malardi, S. pagenstecheri, S. rupestris, S. spirillum and S. tridentatus. 


\section{REFERENCES}

Bergan, P., I953. The Norwegian species of Spirorbis Daudin. Nytt Mag. Zool., Vol. I, pp. 27-48, pl. I.

Borg, F., I9I7. Über die Spirorbisarten Schwedens. Zool. Bidr. Uppsala, Bd. 5, pp. $15-38$.

CAULlery, M. \& MeSNiL, F., I897. Études sur la morphologie comparée et la phylogénie des espèces chez les Spirorbes. Bull. sci. Fr. Belg., T. 30, Sér. 4, Vol. 9, pp. 185-233, pls. 7-10.

Daudin, F. M., I800. Recueil de mémoires et de notes sur les espèces inédites ou peu connues de Mollusques, de vers et de Zoophytes. Paris. [Pp. 33-49.]

De Silva, P. H. D. H., I962a. Experiments on choice of substrata by Spirorbis larvae. Brit. F. exp. Biol. Vol. 39, pp. 483-90.

- $1962 b$. Studies on the biology of Spirorbinae. In the Press.

EAles, N. B., 1939, 1952. Littoral Fauna of Great Britain. 301 pp. Cambridge University Press.

Fauvel, P., 1927. Polychètes sédentaires. Faune Fr., No. 16, 494 pp.

GeE, J. M. \& KNIGHT-Jones, E. W., I962. The morphology and larval behaviour of a new species of Spirorbis. F. mar. biol. Ass. U.K., Vol. 42, pp. 64I-54.

HöGLUND, L. B., I95I. Notes on the morphology and biology of some Spirorbis larvae. Zool. Bidr. Uppsala, Bd. 29, pp. 26I-75.

Levinsen, G. M. R., I883. Systematisk geografisk Oversigt over de Nordiske Annulata, Gephyrea, Chaetognathi og Balanoglossi. Vidensk. Medd. dansk naturh. Foren. Kbh., pp. 92-350, pls. 2-3.

Linnaeus, C., I758. Systema Naturae. Edit. Io. Holmiae. [Pp. 786-9.]

MALM, A. W., 1874. Annulater i hafvet utmed Sveriges vestkust och omkring Göteborg. Göteborgs VetenskSamh. Handl., No. I4, pp. 69-105, pl. I.

MARINe biological association, I93I. Plymouth Marine Fauna. 37I pp. 2nd. ed.

— 1957. Plymouth Marine Fauna. 457 pp. 3rd. ed. [P. I47.]

McIntosh, W. C., 1923. Monograph of British Annelids, Vol. 4, pt. 2, London: Ray Soc. Pp. 25I-538, pls. II 5-38. London.

Montagu, G., I803. Testacea Britannica. London. [Pp. 498-508.]

MOYSE, J. \& NeLSON-SMITH, A., I962. Zonation of animals and plants on rocky shores around Dale, Pembrokeshire. Field Studies. In the Press.

Southern, R., I9I4. Clare Island Survey: Archiannelida and Polychaeta. Proc. R. Irish Acad., Vol. 31, pt. 2, sect. 47, I60 pp. [Pp. I48-9.]

Thorson, G., 1946. Reproduction and larval development of Danish marine bottom invertebrates, with special reference to the planktonic larvae in the Sound (Øresund). Medd. Komm. Havundersog., Kbh., Ser. Plankt., Bd. 4, No. I, 523 pp.

WILsON, R. F., I938, 1940. Horticultural Colour Chart. London: The British Colour Council in collaboration with the Royal Horticultural Society. 